\title{
1. Introduction: geographical political economy, neoliberalism, and the crisis space impedimenta state
}

Capital never solves its crisis tendencies; it merely moves them around. This is what theory tells us, and this is what the history of the past 40 years has been about.

(Harvey 2011: 11, emphasis original)

$[\mathrm{N}]$ ot only do crises get moved around, but crises are embedded in the very structures of what capital accumulation is about.

(Harvey 2016: 55)

The ability to define a situation as a crisis and to prescribe the appropriate response to it is one of the most important expressions of political power.

(Gamble 2014: 32)

Government has a tendency to recreate policies and organisations on an alarmingly regular basis. New organisations replace old ones; one policy is ended while a remark-

ably similar one is launched ... no organisation has survived longer than a decade.

(Norris and Adam 2017: 3)

We need to be clear what the problems are that we are trying to solve. What continues to disappoint me is that we rarely try to define the skills problem, we just endlessly repeat the mantra of having a skills problem, having a skills problem ... What continues to define the agenda is the endless range of initiatives that the skills agenda spawns. So in my time ... we have had Area Manpower Boards, Industrial Training Boards, the MSC, the Training Commission, the Training Agency, Local Employer

Networks, TECs, CCTEs, LSCs, Employment and Skills Boards, and now just announced, Skills Advisory Panels. All these with the professed same aim of bringing to balance the needs of employers with the needs of the local labour market. The very fact that we are still discussing the same issues as we were 40 years ago shows that collectively we are as far as ever from solving the skills problem. And added to that, we have the ongoing programme of new initiatives that are relentlessly launched. So in the last 3 weeks alone, we have seen Ministers make the following statements. $£ 170 \mathrm{M}$ for Institutes for Technology, £10M for Career Learning Pilots, T Levels ...

(Frost 2017: 1) 


\section{INTRODUCTION: IT'S LIKE DÉJÀ VU, ALL OVER AGAIN}

Cities and Regions in Crisis is situated at the heart of debates about public policy: the specific concern is with economic governance- the body of literature associated with the nature and practice of economic management, economic regulation, and, specifically in this book, local and regional economic development as the state project manifestation of this. Economic governance is necessarily broad and covers the ongoing interactions between markets, policies, institutions, and networks, with empirical attention focused on the frameworks and mechanisms underpinning economic development. Over the past century, there have been no states in the West that have fully aimed at allowing free rein to markets; they have always, and in a variety of ways, aimed to organise them. The lessons from Polanyi (1944) and the regulation approach (Chapters 2 and 3 ) is that there have been, and there can be, no markets that do not rely on some rules they cannot themselves set. There is always both a plurality of modes of economic governance and a variety of forms of state intervention to make and regulate markets. Instruments of economic development come into play here and cover the field of: urban and regional policy; training and skills policies; enterprise and business support; infrastructure and services; and the wider realm of fiscal and monetary policies impacting on the local state.

The question of economic governance, then, refers to the mobilisation of available institutional and productive resources to develop a coherent sense of economic identity. In more blunt terms, Farnsworth (2015) posits this a 'corporate welfare' machine of wage subsidies and grants to privately owned companies that both socialise business risks and help to maintain a level of surplus value - in the context of searching for 'frictionless market rule' (Peck 2010: 16). In this context, economic governance, moreover, is a distinctly geographical and seemingly always spatially shifting project: it is constituted in space and remakes the space of such constitutions in the process of performing economic development (Goodwin et al. 2012, 2017). The sub-national territorial space, then, is critical to where economic development has been happening and Cities and Regions in Crisis engages with this changing 'arena of capital' in and through which economic interrelations are being forged (Dunford and Perrons 1983). This introduction lays the foundation for this argument.

The title of this section comes from Yoggi Berra- not the family cartoon character, but the baseball manager and long-time player for the New York Yankees. Berra is well known for his pithy comments and witticisms, known as 'Yogiisms', which often take the form of either an apparently obvious tautology, or a paradoxical contradiction. Local and regional economic 
development in England certainly fits this. The title, Cities and Regions in Crisis, has been deployed to suggest that some of the emerging problems of England's devolution by 2018 uncannily resemble the problems with the new localism of the late 1980s and early 1990s. 'Déjà vu, all over again' ... That was the 'new localism' last time, under the Thatcher and then Major Conservative Party regimes in Britain; now is the 'new new localism' of the Conservative Party government, again. Both moments, 1989 and 2018, though nearly 30 years apart, are very similar in policy architecture, outlook, policy limits, and flaws. Both are business-led and locally based (in rhetoric), involve drawing new boundaries across the local state, have been fired with an all-singing and all-dancing can-do bravado of the enterprise revolution and business-knows-best. But then both experience — strangely enough — a reality of political fiat and central government diktat, experienced on the ground as limited government funding, create a national coordinating body to talk to central government, have limited powers to influence and raise income from the private sector, and exhibit blurred accountability with issues of stakeholder involvement and community input. More importantly, both are private sector ideological solutions to the private sector caused problem of market failure in the skills and employment industry (Jones 2013).

The two state projects in question are the contemporary 'Growth Agenda' Local Enterprise Partnerships (LEPs) and their 'devolved' deal-funding regime, and the 'decentralisation' Training and Enterprise Councils (TECs) trail-blazers of radical Thatcherism and the 1980s enterprise culture revolution. Both suffered whimper noises after big-bang launches. New localist TECs were trumpeted as 'serious business' and 'big business', 'not a quick fix' but 'a network that must stand the test of time' (Training Agency 1989). TECs failed. LEPs, described by Lord Heseltine (2013) as 'the Government's chosen engine of local growth' and by the Department for Business, Innovation \& Skills as 'a real power shift away from central Government and quangos and towards local communities and local businesses who really understand the barriers to growth in their areas' (Business, Innovation and Skills Committee 2013) are also failing to deliver: a symptomatic project of 'compulsive re-organisation'-whereby economic development is a battlefield of the 'wholesale sweeping away and re-creation of organisations and an endless tinkering and meddling with what currently exists' (A. Jones 2010: 374). Both state projects have complete geographical coverage of England, 'make decisions that transcend local administrative boundaries' (HCLG 2018: 22), and are associated with enacting a raft of market-making and economic competitiveness measures, triggering in turn, social cohesion and inequality concerns.

Why are LEPs, and the wider devolution agenda in England, under constant review and failing? As part of a 'local growth' agenda, in 2010 the Coalition government announced that Regional Development Agencies (which super- 
seded some of the functions of TECs) would be abolished and regional economic development would be delivered through the new LEPs, established as locally derived business-led partnerships between the private and public sector that would drive local economic growth. There are now 38 LEPs and their role has developed considerably since 2010. Under the Conservative administration (from 2015-) LEPs now have responsibility for around $£ 12$ billion of public funding and are the mechanism for channelling the Local Growth Fund to localities. In contrast to what had come before-' 'a century of centralisation' with 'anti-localist measures', expense, bureaucracy and the erosion of local voice-for Government, initiatives such as LEPs instead represented 'control shifts' in the devolution of power and responsibility from the central state to local communities (Conservative Party 2009). LEPs accordingly would offer a clear vision and strategic leadership to drive sustainable private sector-led growth and job creation in their area. Eight years on, a major review is underway to produce a 'revised national assurance framework' (HCLG 2018), as strategy, funding and resource, and geographical issues run deep. The government has provided limited core funding, which pump-primes business engagement activities and allows for the employment of core staff. Outside this, LEPs are expected to use their powers of business influence and coercion to raise funds from the private and public sectors to make things happen. This is proving to be problematic. LEPs have responsibility over local business and communities but are without powers. Some critics are arguing for revenue-raising powers, with the government response being that this could potentially damage their reputation and standing within the business community (Jones 2013).

Critiques also point to the lack of legal and statutory foundations, the inability to procure contracts, and an ability to manage programmes properly due to limited running costs (see Etherington and Jones 2016a; Pike et al. 2015, 2018). Like multiple economic and social development state projects before them, LEPs are bound up in a multi-scalar game of relationship jockeying, which is bringing with it concerns of responsibilities and representation. On one upward level this relates to relationships with Whitehall government departments. On a downward level, it touches on issues of board membership and accountability. Lobbying is prevalent for increased local flexibility, given the need to hit government targets for the funding streams, and also to be seen to be doing interesting things locally. The 'blancmange' of government and lack of coordination in Whitehall makes attaining and maintaining sustainable business leadership a real challenge for LEPs (Jones 2013). A cyclical isomorphic dysfunctionalism, stemming from the 'short termism of programmes, policies, and institutions [reproduces] the uncertainty and unwillingness of business and other stakeholders to invest in relationships [and] leads to a loss of institutional memory and tactic knowledge in the region' (Fairburn and 
Pugh 2010: 1). 'Politically conditioned institutional instability', as Fairburn and Pugh add (ibid:1), runs deep.

Rewind 30 years and hear the same concerns ... TECs were proposed in the Employment for the 1990s White Paper, December 1988. Like the LEPs, TECs had deep inherited institutional legacies and were always going to be better than previous moments of institutional change. Similar to LEPs, the narrative suggested that public sector conceived agencies have sought to tackle the issues of economic change. The outcome, in many respects, was unsatisfactory. They failed (see Peck and Jones 1995; Jones 1999; cf. Bennett et al. 1994). Like LEPs, they were an example of a new institutional form of governance being forced to fill two roles. TECs were first a customer of government and, second, saw their communities as clients. TECs, then, like LEPs, were unaccountable by design. Board directors were appointed as individuals and were not representative of any organisation that could remove or replace them. TEC boundaries, as for LEPs, were not centrally prescribed. This did not, however, hide the fact that TECs were, like LEPs, explicitly central government creations. TECs talked about the training market, but this was based, like LEP initiatives, on central government funds, public funds, in which the parameters and the incentives for action were determined by central government. South Thames TEC went bankrupt for trying to operate outside this (Jones 1997a) and Greater Cambridge/Greater Peterborough LEP was investigated for trying to abuse this, with conflicts of interests and financial irregularities being reported (National Audit Office, 2017).

In short, a 'British vice of perpetual restructuring' is eating away at local economic development in England, where 'the whole system is paralysed by uncertainty about who will be left standing when the game of musical chairs comes to an end' (Mulgan 2010: 1). More fundamentally, for Pike and colleagues, these neoliberal models of economic development are at a critical crossroads: we have lost sight of what local and regional economic growth and development is for; who is involved, why, who benefits; there is a consensus things aren't working through decentralisation, but there are also limited offerings on where to go next (Pike et al. 2015, 2016a, 2018). As noted by Frost (2017) above, those deeply involved in economic development do not disagree with this history and its critique. The challenge is contextualising and explaining all this: how we ended up here, what it means, and why this matters.

\section{EXPLAINING SHIFTS WITHIN LOCAL AND REGIONAL ECONOMIC DEVELOPMENT}

Cities and Regions in Crisis maintains that these opening remarks are not cursory or speculative glances through the rear-view mirror of state intervention in economic governance taking the form of local and regional economic 
development. These public policy histories and legacies have been subject to much scrutiny. In recent years, further reports have highlighted the 'endless tinkering' of government policy with respect to local and regional economic development in England. A particularly hard-hitting and historical significant report published in 2017 by the Institute for Government (IfG), aptly titled All Change: Why Britain is so Prone to Policy Reinvention, and What Can Be Done about It, claims that considerable damage is being done to economic governance and public policy generally by such perpetual tinkering, the rationale of which is startlingly unclear. With 28 changes to legislation and 48 Secretaries of State in 30 years, the IfG review looked into the now extreme rapid rate of change to government policies and how this had affected many sectors, including regional government, as well as industrial strategy and further education.

The reason for the changes, or an 'appalling churn' as the IfG called it, could be put down to a number of factors, including disagreement about the purpose of regional governments, or the appropriate spatial level at which to devolve powers and Whitehall's unwillingness to trust existing local institutions, but opinions from documentary research were uneven and inconclusive. In short, the 'constant reinvention' in these three policy areas and more widely in government, noted as one of 'redisorganisation' and 'accordianisation' - the need to keep everyone confused by instituting continuous centralisation and decentralisation - could not be adequately explained. 'In the space of just over 20 years, the main vehicles for regional governance have included government offices, regional assemblies, regional development agencies and, currently, local enterprise partnerships', the report stated, with the annual cost of continual reorganisation for a single government department alone costing around $£ 15$ million a year (Norris and Adam 2017: 3).

Put simply, IfG researchers, and a launch panel (held on 14 March 2017) consisting of former permanent secretaries and other senior policy-makers, did not know whether these perpetual and cyclical changes have been taking place due to the new policy challenges facing local and regional economic development in the midst of globalisation, or whether policy change is a response to repeated policy failures and, linked to this, ad hoc political interference vis-à-vis ideological change without an evidence-base. Skills policy, for instance, is deemed 'vulnerable to churn' due to it being the domain of junior ministers, rather than this being interpreted as the obvious place where market failures are prevalent and increasingly endemic under neoliberalism (see Offe 1985; Peck 2010). As Dunford and Perrons (1992: 398) summarise: '[s]kills and training make up another area in which unregulated market mechanisms are, in fact, self-destroying'. The IfG's detailed policy reflections are captured in Figures 1.1, 1.2, and 1.3, which clearly show the churns in skills strategy, 
regional government, and industrial policy accelerating rapidly over time with respect to policy, structural and personnel changes.

The IfG 'patterns of churn' analysis is not isolated; it builds on a key intervention offered by the National Audit Office on the Funding and Structures for Local Economic Growth. This landmark report acknowledges that addressing uneven economic growth between and within regions has been a focus of government policy for a number of years and thus a legitimate object of state intervention. Local 'growth policy', though, has seen a sequence of initiatives over a number of decades where structures and funding regimes are often replaced by new schemes (see Figure 1.4). With some 38 changes to the landscape of economic development since the inception of urban policy in the early 1970 s, again staggering in itself and not explained by the authors (other than it represents 'poor value for money'), the phase of change in place since 2010 is deemed to be 'distinctive' because:

it has entailed the almost complete removal of existing structures and funding for local growth, both locally and regionally, and their replacement with new structures and funding, local freedoms and responsibilities. In contrast, previous phases of change have tended to be incremental and overlapping. As we have reported previously, reorganisations can be poor value for money due to poorly specified objectives, limited cost and benefit monitoring, and poor implementation planning. (National Audit Office 2013: 16)

Asking the central question of what indeed is happening in Britain (and England specifically), Cities and Regions in Crisis shines a light on, and begins to explain, these geographical peculiarities of state intervention. In stark contrast to many of the academic offerings on local and regional economic development over the past 20 years (see journals such as Local Economy, Policy and Politics, Journal of Urban Regeneration and Renewal, etc. and the many conference presentations that I have witnessed between 1993 to 2018), which frequently fetishise and evaluate policy on self-referential terms, and are always surprised that 'top-down' state intervention seems to somehow fail 'bottom-up' localities, Cities and Regions in Crisis considers why, and in what ways, particular policy problems are constructed and reveals the economic, political, and social processes through which spatial scales and regulatory governance mechanisms become codified as the solution to such problems. It considers this to be important not only to explain the inability of state intervention to make a difference, given that academic and popular analysis has highlighted the widening and deepening of uneven development across the UK and the extension of the North-South divide (McCann 2016). Cities and Regions in Crisis offers a political economy 'explanatory power' - that which highlights the mechanisms that best explain the events observed (Sayer 1992) - and argues that it is academically and politically essential to draw 


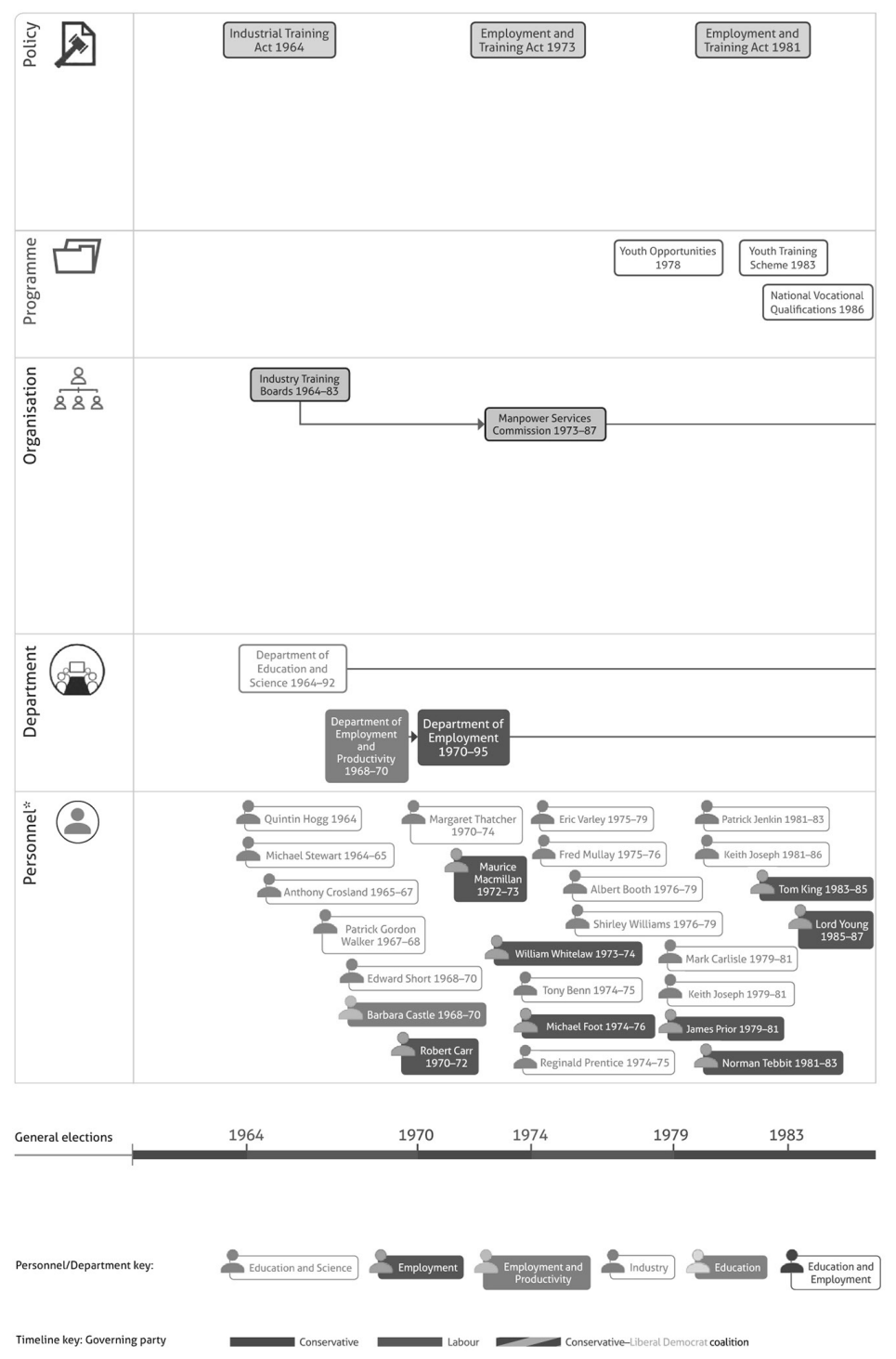

Source: For a colour version, see Norris and Adam (2017: 6-7; https://www.institutefor government.org.uk/sites/default/files/publications/IfG_All_change_report_FINAL.pdf), design by Sarah Henley. Information correct as of March $201 \overline{7}$.

Figure 1.1 Churn in the further education sector: a timeline of policy, structural and personnel changes 




Figure $1.1 \quad$ Continued

attention to how seemingly unconnected processes of state restructuring and policy formation are in fact differentiated outcomes of ideologically infused political decision-making that cannot be separated from the inherent crisis tendencies and contradictions of capital accumulation, state formation, and state intervention. Put simply, policy failure is not a random and surprising 


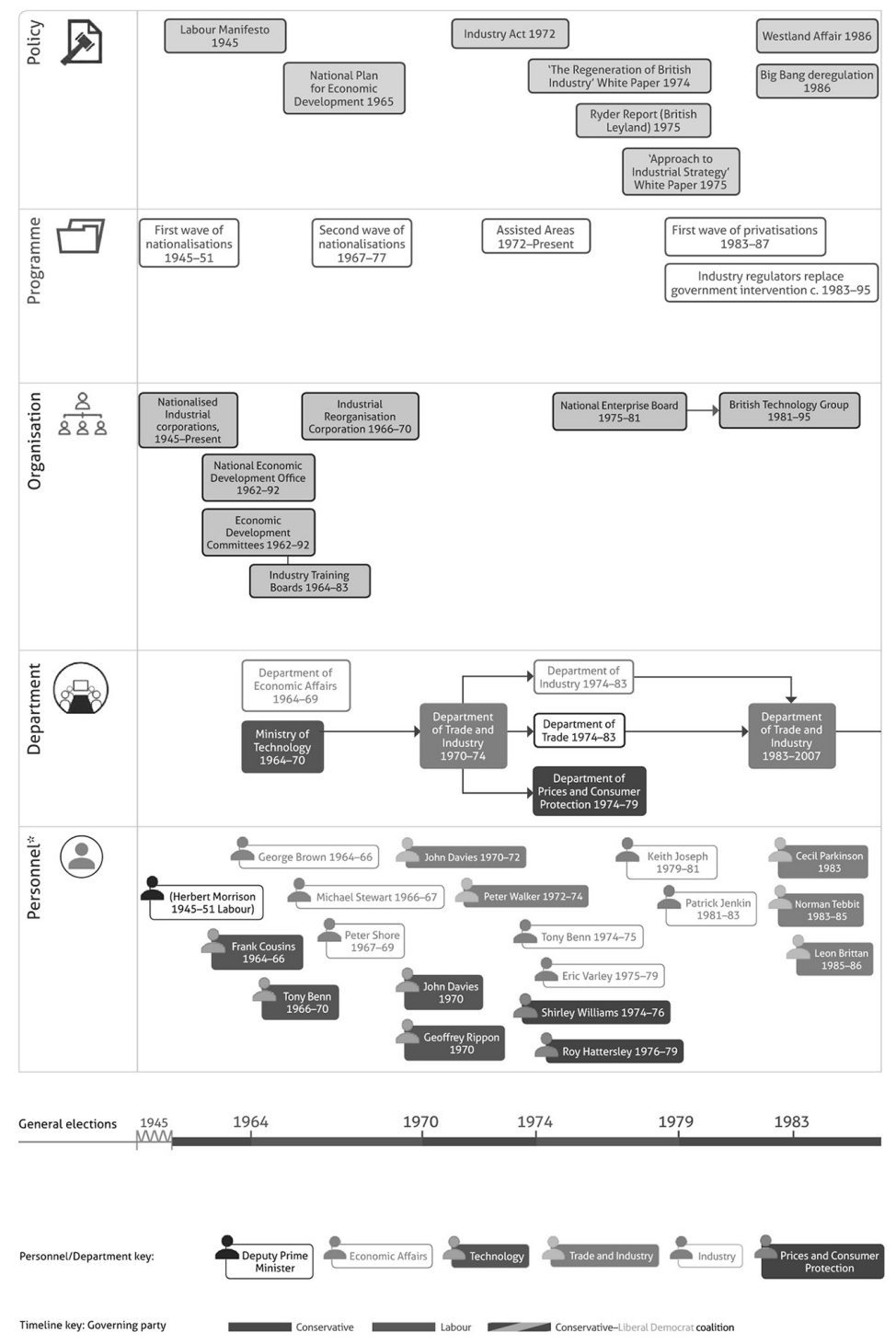

Source: For a colour version, see Norris and Adam (2017: 12-13; https://www.institutefor government.org.uk/sites/default/files/publications/IfG_All_change_report_FINAL.pdf), design by Sarah Henley. Information correct as of March 2017. Figure $1.2 \quad$ Churn in regional government: a timeline of policy, structural
and personnel changes 


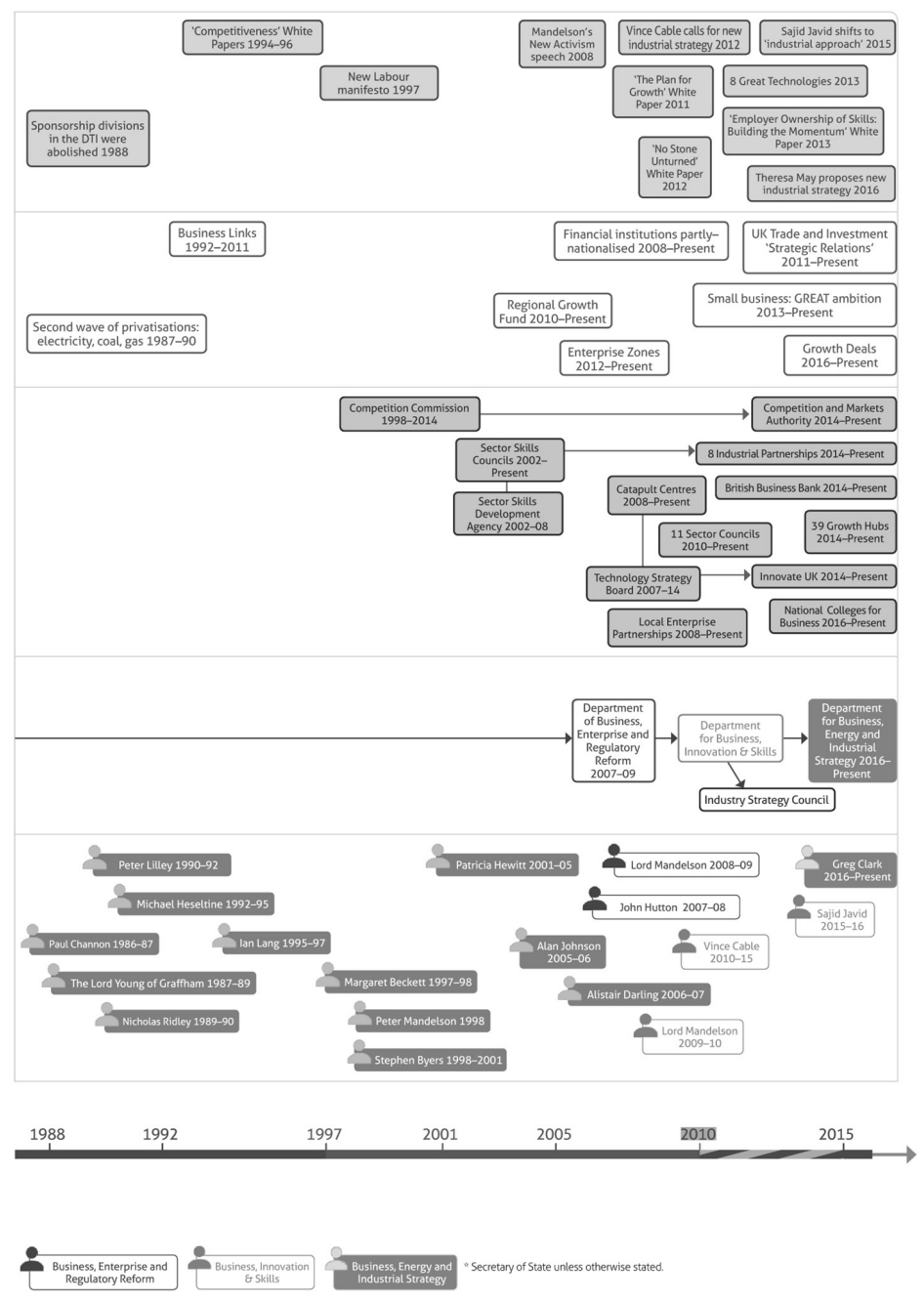

\section{Figure $1.2 \quad$ Continued}

phenomenon; it is the norm and increasingly endemic to advanced capitalism and its late neoliberalism spatial forms.

Following the entry quotes from Harvey $(2011,2016)$, Cities and Regions in Crisis suggests that the problem of economic development has indeed been continually moved around. Contradictions necessitate displacement and 


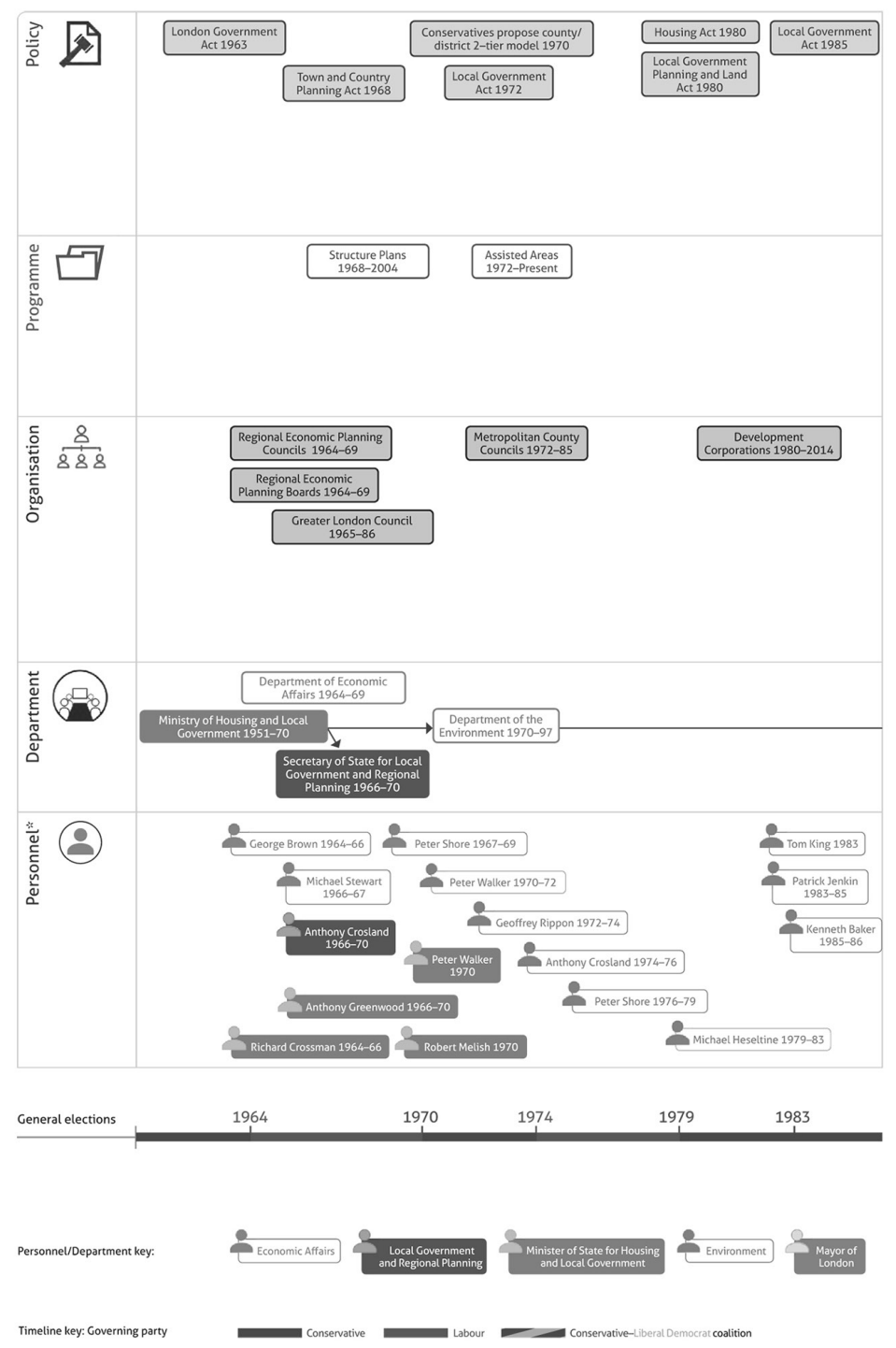

Source: For a colour version, see Norris and Adam (2017: 18-19; https://www.institutefor government.org.uk/sites/default/files/publications/IfG_All_change_report_FINAL.pdf), design by Sarah Henley. Information correct as of March $201 \overline{7}$.

Figure 1.3 Churn in industrial strategy: a timeline of policy, structural and personnel changes 


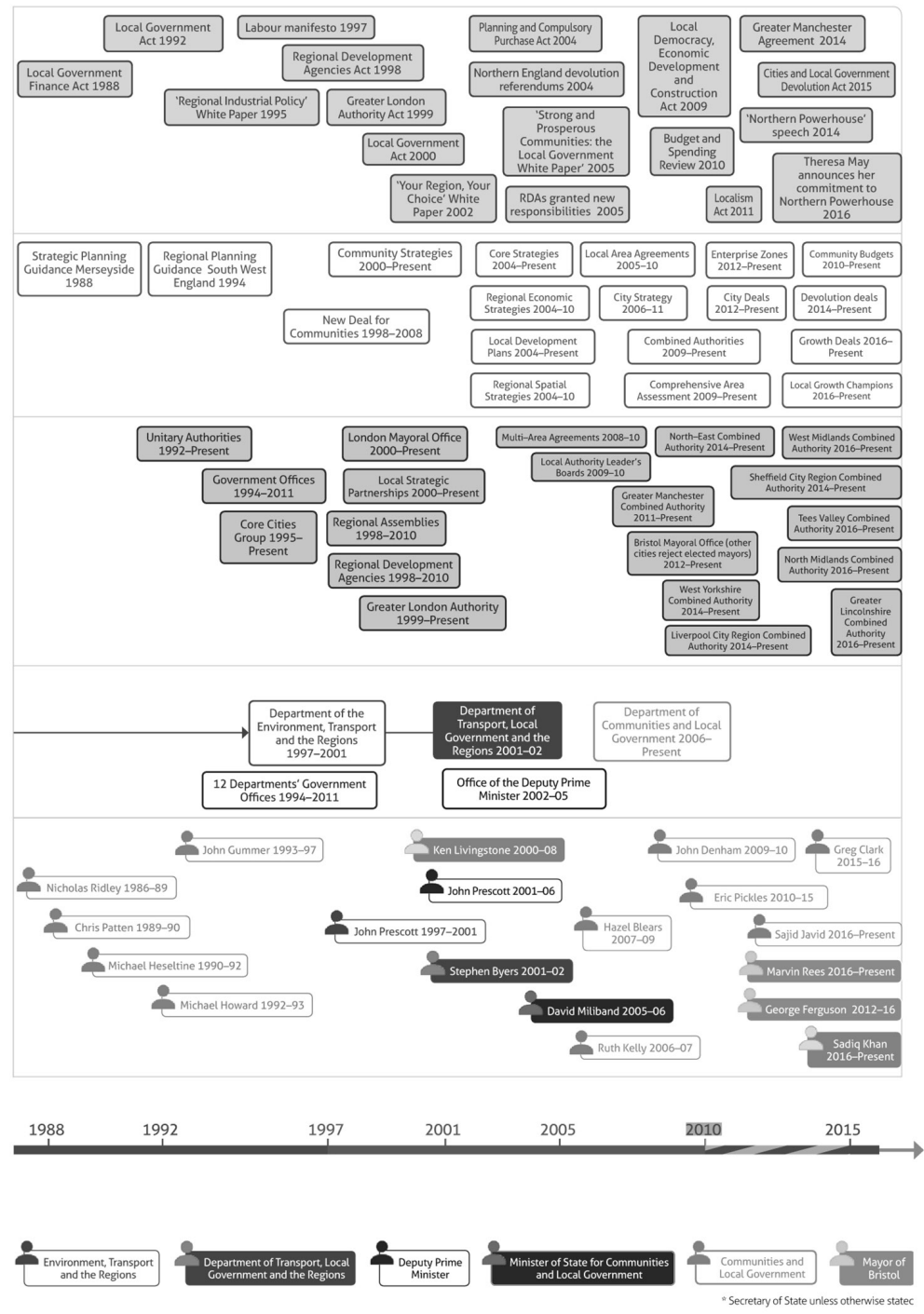

\section{Figure $1.3 \quad$ Continued}




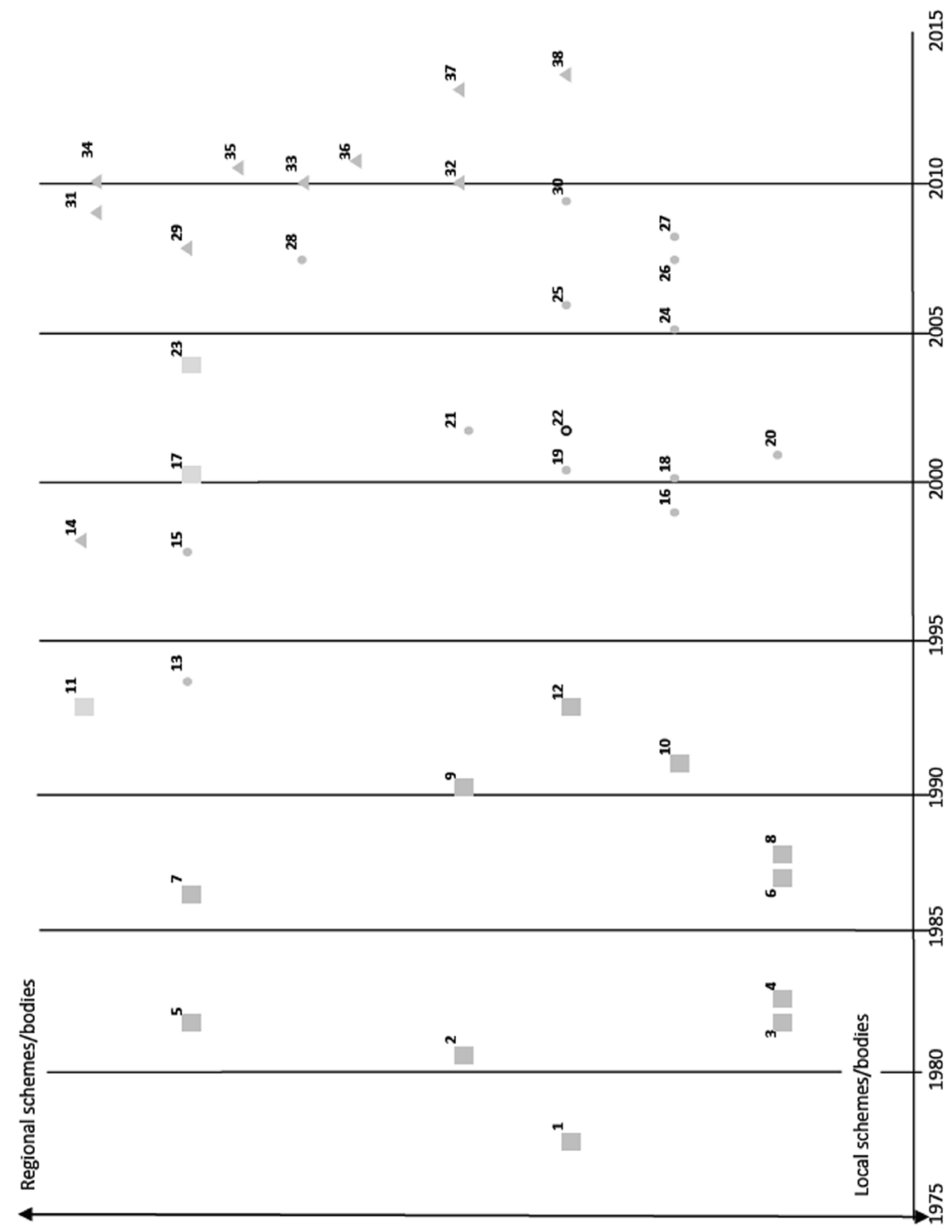

Source: Pike et al. (2018: 137) based on National Audit Office (2013: 17).

Figure 1.4 Evolution of initiatives for local growth in England, 1975-2015 

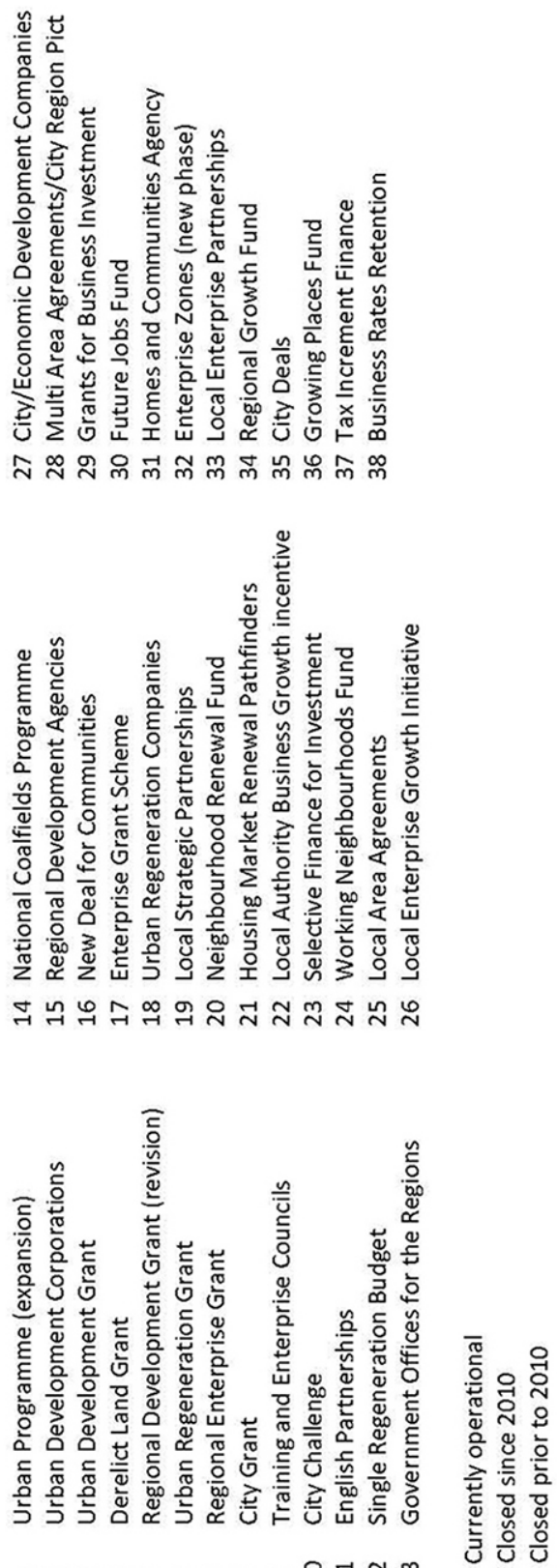

Figure 1.4 Continued 
transformation, but the crisis-management strategies of the state themselves are always subject to new forms of crisis tendency, which points to the always unstable nature of economic governance and economic development. The evidence in Figures 1.1, 1.2, 1.3, and 1.4 does not point to a coherent institutional-fix that supports this neoliberal growth project, but is instead best regarded as heterogeneous, mutable, and involving variegated responses and producing unstable uneven geographical outcomes (Allmendinger and Haughton 2015). Peck denotes this as public policy 'failing forward' in that 'manifest inadequacies have-so far anyway-repeatedly animated further rounds of neoliberal invention. Devolved governance, public-private partnerships, management by audit, neopaternalism ... all can be seen as examples of institutional reinvention spawned as much by the limits of earlier forms of neoliberalization as by some advancing "logic"” (Peck 2010: 6-7). A geographical political economy framework for grappling with this is desperately needed and delivering on this behoves: first, a consideration of the relationship between geography, public policy, the state, and space; second, a long-run analysis of the historical specificities, trends, and counter-trends of state intervention within capitalism; and, third, the interconnecting of analyses of economic development with changes in social policy, given the wage-relation and value-relation aspects of capitalism within which state intervention occurs (see Chapter 3; also Offe 1984: 92). The unpacking of this argument and signposting of the chapters and moments contained within Cities and Regions in Crisis to demonstrate this is outlined below.

\section{GEOGRAPHY, SHALLOW, AND DEEP POLICY ANALYSIS}

The relationship between geography and public policy - defined as 'any form of deliberate intervention, regulation, governance, or prescriptive or alleviative action, by state or nonstate bodies, intended to shape social, economic or environmental conditions' (Martin 2001: 206) — has been subject to debate in the past two decades, with geographers working 'themselves up into quite a lather' (Massey 2002: 645). Peck (1999a) has made a critical distinction between 'shallow' and 'deep' public policy analysis. 'Shallow policy analysis' is research confined to addressing the 'stated aims and objectives' of policies from within an orthodox theoretical position. This often serves the needs of the policy-making system, which it takes for granted, by licensing quick-fix solutions. By contrast, 'deep policy analysis' takes a theoretically unorthodox position and questions the embedded and path-dependent nature of public policy. Deep policy analysis, therefore, delimits research that engages 'critically and actively with the policy process itself' (Peck 2000: 255). Key here is teasing out relationships between different levels of public policy 'to connect 
together the smaller pictures with the bigger pictures of the policy process, to connect the specific with the general, without undermining the integrity of our particular take on the policy process' (Peck 2000: 257). As the IfG report above highlights, some 20 years later, the political economy of the policy process - linked to how we conceptualise the capitalist state, its organisation, and its modes of intervention-remains a gap in our understanding.

Put simply, successful policy-making depends on an understanding of the policy process itself, which, in turn, depends on some appreciation of the structure of power in society, which, in turn, requires a critical appreciation of the state. We need to focus on how government responds to and represents its 'wider social environment' (Jessop 1990a). State intervention constitutes a 'moral geography': by understanding the social situations and politics that go hand in hand with forms of state intervention, we can go some way to understanding what makes public policy tick, and why these churn-changes within economic development have been taking place. To understand local and regional economic development, we need to understand the multiple geographical terrains of the capitalist state and state-making processes - the main arena in and through which public policy is made and coordinated - and how this relates to the regulation and governance of capitalism, its contradictions, and crisis tendencies.

\section{STATES, ECONOMIC DEVELOPMENT AND GEO-PERIODISATION}

Capitalist development is inherently and unavoidably uneven, contradictory, and anarchic. Attempts to manage it more smoothly via state activity do not abolish these contradictions but instead internalise them within the state itself. There may be periods when it may seem as if the contradictions have disappeared and that the interests of capital and labour are, after all, compatible; that capitalist development can, in a sense, be successfully managed by the state. But such periods reflect combinations of contingent circumstances, which disguise but do not abolish the deeper contradictions. In due course these re-emerge. (Hudson 1989: 386)

The most general feature of the state (pre-modern as well as modern and pre-capitalist as well as capitalist) is that it comprises a set of institutions concerned with the territorialisation of political power. This involves the intersection of politically organised, coercive, and symbolic power, a clearly demarcated core territory, and a fixable population on which political decisions may be made collectively binding. Thus, the key feature of the state is the historically variable ensemble of technologies and practices that produce, naturalise, and manage territorial space as a relatively bounded container within which political power is exercised to achieve various, more or less well-integrated, and changing policy objectives. The state, then, is distinct and 
different from say a multinational corporation, by virtue of its territorial integrity and its political legitimacy. The state is also different in the various roles that it can play. As Hudson $(1989,2001)$ above reminds us, states can respond to the contradictions, dilemmas, and problems of capitalism by creating the general conditions for the production and social reproduction of the capital relation, that is, the environment for economic growth and development. The state does this in part by seeking to promote growth and development and/ or by responding to the effects of this, that is, uneven growth, change, and restructuring. The state though is omnipresent: due to its development and penetration into most spheres of life, it appears to be everywhere and nowhere at the same time.

Following Gramsci (1971), the state is a complex and broad set of institutions and networks that span both political society and civil society in their 'inclusive' sense. Building on this insight, states can be viewed as strategic terrains, with emphasis being placed on strategic considerations and strategic actions. Offe $(1975,1984,1985)$ discusses this arrangement by drawing attention to the state and its circuits of power and policy implementation, which provides a window on the patterning of state intervention and the everyday nature of policy-making under capitalism. Building on Offe and Gramsci, Jessop's approach to the state, which is peppered throughout Cities and Regions in Crisis and further developed in Chapter 10, has significantly moved forward these arguments. For Jessop, the state needs to be thought of as 'medium and outcome' of policy processes that constitute its many interventions. The state is both a social relation and a producer of strategy and, as such, it does not have any power of its own. State power in relation to the policy process relates to the forces that 'act in and through' its apparatus. According to this view, attempts to analyse the policy process need to uncover the strategic contexts, calculations, and practices of actors involved in strategically selective, or privileged, sites (Jessop 1990a, 2016a). This can be summarised as a framework that demonstrates 'systems analyses' for the undertaking of 'systematic' forms of public policy analysis - drawing attention to the intricate links between actors and forms of representation, institutions and their interventions and practices, and the range of policy outcomes available. The state, then, is both a strategic and relational concern, forged through the ongoing engagements between agents, institutions and concrete policy circumstances. This seeks to get to the heart of the 'policy process itself' and the why, where, and when of local and regional economic development.

Rhodes (2007: 1254, emphasis added) reminds us that 'patterns of rule arise as the contingent products of diverse actions and political struggles informed by the beliefs of agents as they confront dilemmas that are understood differently in contending traditions'. Heeding this call for causal explanations of state intervention, where the uncovering of apparent purpose matters, two 
crucial elements of statehood and policy-making, which run through Cities and Regions in Crisis, need to be considered. The first is the notion of 'discursive geographies' (Jones 2008). This encourages us to think of the state as not 'always-already there': the relationship between states, ideology and discourse matters in and through the production, dissemination and consumption of ideas and concepts to understand the whereabouts of state intervention and public policy. As the empirical evidence above (Figures 1.1-1.4) and below in the chapters of Cities and Regions in Crisis documents, new institutions are continually being built by the state and cadres of 'experts' strategically assembled that can be proposed as the appropriate caretakers, teachers, and practitioners of knowledge. As knowledge is transferred, though, 'from one scale to another, the particular social, political, and economic context within which it was produced is stripped away, allowing the presentation of abstract programmatic statements that are valorised as universally applicable' (Dixon and Hapke 2003: 143).

Second, the 'geography of discourse' (Jones 2008) itself matters, i.e. the way objects of regulation and governance are constituted in relation to each other. The construct of policy does not stand independently from the ideas and beliefs of politicians and policy-makers, but has to be always contextualised in relation to concepts and ideas that are unstated. For Dixon and Hapke (2003: 143), the state is able to establish this line 'via the play of binaries for example, free/fettered, family/corporate, rural/urban, welfare/investment, safety/risk, individual/ social, us/them — one side of each of which becomes prioritized to the detriment of its opposite' (Dixon and Hapke 2003: 143). Sum and Jessop (2013) deploy the notions of 'semiosis' and 'construal' to combine these twin insights. Semiosis refers to sense-making and meaning-making, whereby policy-makers can give appreciation and meaning to their actions world', which is in turn predicted on 'construal'- how a particular policy problem is perceived and the solution constructed in response to this. Put very simply: 'Policy makers are not faced with a given problem. Instead they have to identify and formulate their problem' (Lindblom 1968: 13) and 'the definition and construction of a "problem" contains within it the "solution" to that problem" (Atkinson 2000: 211, emphasis added). Hadjimachalis usefully adds:

When failures turn to crises, those actors who are capable of making decisive interventions, apart from acting to 'solve' the problem, promote a particular discursive construction of the crisis, suitable to their interests. In this mediation, powerful actors [play] key roles, such as the mainstream media, politicians, bureaucrats and European, national and international institutions, bankers and think tanks. In doing this, old and new imaginations, prejudices and 'scientific' analyses [are] mobilised, targeting mass public moral sentiments and beliefs. (Hadjimachalis 2018: 79) 
Economic development is no exception here and the nature of the problem and the solutions to this have changed considerably over time and across spaceperpetually in a state of flux, as noted above.

These concerns can be further rolled together through the idea of 'spatial fixes' (see Chapter 3) and 'spatio-temporal fixes' (see Chapter 10), both concepts deployed to comprehend the dynamics of state spatiality, state spatial restructuring, and the geographies of state intervention specifically. The state performs the role of securing the relative stabilisation of society by endeavouring to manage the various economic and political contradictions within the state system (Hudson 1989). This is inherently spatial, as state intervention is articulated through the constructions of spaces (scales, levels, horizons, etc.) of intervention, the fixing of borders, the stabilisation of places, and, in short, attempts are being continually made to produce and reproduce a territorially coherent and functioning socioeconomic landscape.

This has been referred to elsewhere as state 'spatial selectivity' - the processes of spatial privileging and articulation in and through which state policies are differentiated across territorial space in order to target particular geographical zones, scales, and (organised and disorganised) interest groups (Jones 1997b, 1999; see also Omstedt 2016). The latter dimension forms an integral element of how political structuration occurs within the state apparatus via the creation of territorial coalitions, or what Cox (1998) calls 'spaces of engagement', to mobilise strategically significant actors and exclude others where 'spaces of dependency' (interests and attachments) rule out their possibility for incorporation. The tension between engagement and dependency, of course, creates a politics of scale and a scaling of politics, where some localities are either more or less engaged in networks of association beyond their immediate territories than are others (see Jonas and Wood 2012).

As noted previously (Jones 2009), Brenner's (1998: 474-477) work on state spatiality offers a useful geo-periodisation bridge to frame this, alongside which the arguments within Cities and Regions in Crisis on the spatial selectivity of local and regional economic and social development can be discussed. Brenner draws attention to three periods: 'encagement' (1890s-1930s), 'entrenchment' (1950s-early 1970s), and ‘de-nationalisation' (post-1970s onwards), which are unpacked in turn.

\section{Space of Localism: Municipal Local States}

Taking these in turn, until the late nineteenth century, there was a distinct polarisation between industrialising city-regions and predominately rural agricultural peripheries, which was reinforced at a global scale through colonialism and imperialist expansion. The global depression of the late 1890s and after, however, drove a search for a state-managed and organised 
capitalism. With the development of market societies, 'states were forced to adopt measures to prevent the self-destruction to which self-adjusting markets were inclined' (Dunford and Perrons 1992: 391). An emerging 'encagement' of socioeconomic relations was taking place due to the increasing spatial convergence between the interests of capital and the state, which fuelled the development of global urban hierarchies and increasingly territorial states (Brenner 1998: 473). Geoeconomic interests began to dominate here and the continued expansion of capital growth and development drove the search for a spatial symmetry between a national economy, state bureaucracy, civil society, and national culture, all feeding each other. This was secured through mainly public infrastructure development across territorial space, industrial infrastructures, national economic planning, and an expanding state apparatus.

Over a 40-year period, the state thus acquired a major role in the construction of numerous interlocking territorial infrastructures-public transportation, education and housing facilities, communication networks, utility supplies, and other aspects of the expanding urban and regional fabric - as market mechanisms of distribution had failed as mechanisms of production and modernisation. Economic development trajectories in England broadly align to this. Victorian 'localist' public health legislation, for instance, made possible the expansion of the (local) state's roles in responsibility for water and sanitation through a combination of local taxation and municipal trading. The context for these local rounds of state intervention was 'countering localized market failure' (Hall 2016: 313) and as the nineteenth century progressed, other services were developed in a similar way, including gas, electricity and public transport (Ward 1988).

\section{Spatial Keynesianism: National Welfare States}

Following the Great Depression of the 1930s, and certainly after the Second World War, this model of statehood was consolidated through modernisation, nationalisation, and rationalisation to make space for a new wave of capitalist expansion, despite the onset of serious and lasting economic crises. Britain, for instance, faced growing international competition and local authorities experienced economic problems that precipitated engagements with industrial promotion activity, which accelerated in the inter-war years. As Mawson points out:

The fact that the burden of addressing the social consequences of mass unemployment was borne at the local level through poor relief further encouraged local municipal leadership to promote the local economy and associated tax base. In some areas this development took places as an adjunct to central government's emerging regional policies as heralded in the 1934 Special Area Act. (Mawson 2009: 40) 
These emerging regional policies were seeking to deal with the problems of uneven development and rising spatial inequality between a growing south and declining north. Consequently, throughout the Fordist-Keynesian period, roughly from the 1950 s to the early 1970 s, the role of the territorial state as a geographical container of capital accumulation and social development intensified and solidified (Brenner 1998: 474). From the 1930s, states had begun to engage directly in attempts to devalue and revalue capital through subsidies, grants, loans, tax advantages, public investments, and state ownership of production facilities. In Britain, for instance, the Barlow Commission of 1937-1940 was a landmark event, which placed a national duty on government to control capital to prevent the overheating of London and the South East and argued for national control of industry through planning. The spatial distribution of capital via the levers of industrial and regional policy followed (see Hall 1989) in the increasing context of also attempting to deal with, and counteract the problems with, a 'Britain in decline' (see English and Kenny 2000; Gough and Eisenschitz 1996a, 1996b) growth model, where:

British capitalism does not work, because it is a competitive system in which private profit is and must be the main objective. It is a system in which all the prevailing forces are pulling in opposite directions and the interests of the individual are as often as not opposed to those of the state. (Orwell 1940: 50)

This practice of capital regulation and spatially targeted investment progressed through rounds of regional policy, such as the Local Authorities (Land) Act 1963 and The National Plan, with regional and local state institutions becoming 'transmission' for interventionist central state policies concerned with addressing 'the balance of payments [via] an intensive effort by all concerned' (HMSO 1965: A3). Their goal was simultaneously to maximise growth by 'overcoming the obstacles to growth' (HMSO 1965: A3) and to redistribute its effects as evenly as possible on a national scale. Between the 1950s and the 1970s, further rounds of regional (industrial) policies, such as the Hunt Report on Intermediate Areas, were introduced to promote industrialisation within each state's under-developed peripheries. The spaces mostly outside declining cities became hosts to industrial estates, employment parks, and other exhibits of fixed-capital investment to attract jobs through inward investment, as well as growing (often failing) local/regional economic talent. This was supported by the expansion of the welfare state, increasing universal rights and social citizenship, and politics predominately related to achieving and raising social benefits. The state's role in territorialising capital and in securing a spatio-temporal fix for social relations, therefore, converged around the nation state. In this manner, the "national scale operated as the critical geographical framework for capitalist production and exchange, as the dominant 
institutional site of sociospatial polarisation, and as the most central arena for addressing sociopolitical contestation' (Brenner 1998: 475).

The crises and contradictions of capitalism were in effect delicately balanced, or what Dunsire (1993: 11-12) calls 'collibrated', into a durable spatio-temporal fix. As Lefebvre (1976: 111) puts it: 'the ship of capitalism and its leaders found itself with a motor, a rudder and a fixed course'. The limits to this became apparent during the mid-1970s with the collapse of Atlantic-Fordism (see Chapters 2 and 3). Key for Britain was social and political unrest, with the government responding with the raft of state interventions on urban policy ignited by the 1977 Urban White Paper and 1978 Inner Urban Areas Act (Chapter 3), where 'local economic development was encouraged by the policy vacuum created by the retreat of national regional policy in areas of increasing unemployment and by the introduction of locally delivered national schemes such as the Urban Programme' (Mawson 2009: 41).

\section{De-Nationalisation Scalar Relativisation: New Localism and New Regionalism}

Consequently, 'de-nationalisation' (Brenner 1998: 475) has had more profound implications on geography of world capitalism and the political-economic geography of the state than the two preceding waves of spatio-temporal fixing. Shifts within the international division of labour, aided by technical change, brought about intense economic restructuring, which transformed some industrial heartlands into wastelands and provided new post-industrial opportunities for others. Accordingly, on sub-state levels, 'interspatial competition' has intensified among cities and regions competing with one another to attract capital investment and secure state subsidies (Brenner 1998: 475). In addition to these globally induced reconfigurations of the national scale, there has been a series of highly contested forms of reterritorialisation involving the state and its interventions, restructuring impacts, and responses to this. Two overarching broad trends are worth mentioning and these have been defining research agendas in political geography and human geography more broadly in recent years.

First, scholars have highlighted a 'relativization of statehood' (Collinge 1999). In contrast to the era of Fordism-Keynesianism, described above, there is no privileged level around which the state can influence the unfolding of capitalism. The relativisation of statehood thus implies: (1) an increasingly tangled hierarchy of overlapping, continually changing arrangements associated with multilevel interventions; and (2) the systematic lack of any dominant scale, or system of governance, that encompasses or subsumes competing scales of political-economic organisation. To understand this, the crisis of Fordist capitalism and the subsequent burst of globalisation should be 
understood as a de-centring of nationally scaled regulatory arrangements, as sub-national and supra-national scales of political-economic life have acquired a renewed, and in some cases unprecedented, significance through a variety of trial-and-error, often ad hoc, political initiatives, in especially economic development. This often involves the shift from government to governance, as new arrangements for state management now involve an array of different socioeconomic partners and not just those in formalised state structures (Chapter 2).

Figure 1.4 captures some of this, with an increasingly relativisation of scale and an almost 'filling-in' (Goodwin et al. 2012, 2017) of all horizons (national, regional, local) of state intervention. While the Keynesian welfare national states of the post-war era were intent on harmonising the equalisation of wealth, population, and infrastructure across national territories, contemporary neoliberal state projects are promoting territorial competitiveness within certain strategic sub-national sites such as cities, city-regions, and industrial districts, which in turn are to be positioned within supra-national and global circuits of economic development. While certain aspects of this entrepreneurial reorientation of local and regional policy has occurred from below, as fiscally stressed localities and regional states have attempted proactively to attract new sources of investment through the actions of development agencies and other institutions, sub-national economic development must also be construed, to a significant degree, as national state projects concerned with providing 'new avenues for capital accumulation' (Hadjimachalis 2018: xii) by increasing the reach and depth of state-space.

Second, accordingly provoked by hegemonic discourses of globalisation and business civilisation alongside a political rhetoric of fiscal prudence, national states have actively sought to reduce commitments to integrated welfare entitlements and redistributive urban and regional policies in favour of supply-side neoliberal initiatives intended to promote technological innovation, labour market flexibility, lean management, and endogenous growth. This is discussed further below.

As outlined in Chapters 2 and 3, Metropolitan County Councils were abolished in Britain, reflecting central government's hostility to their deemed to be socialist interventionist range of economic development policies, and 'new localist' state-sponsored institutions, such as Urban Development Corporations (UDCs) and TECs (noted above), put in their place. The 'patchwork quilt' (Audit Commission 1989) of local complexities was replaced by a 'new regionalist' 'bowl of spaghetti' (Johnstone and Whitehead 2004) of responding to new market opportunities through new forms of organisational capacity and business leadership through Regional Development Agencies (RDAs), working in tandem with, but also getting tangled-up with, Local Learning and Skills Councils (Chapters 5, 6 and 7). In the words of the Lord 


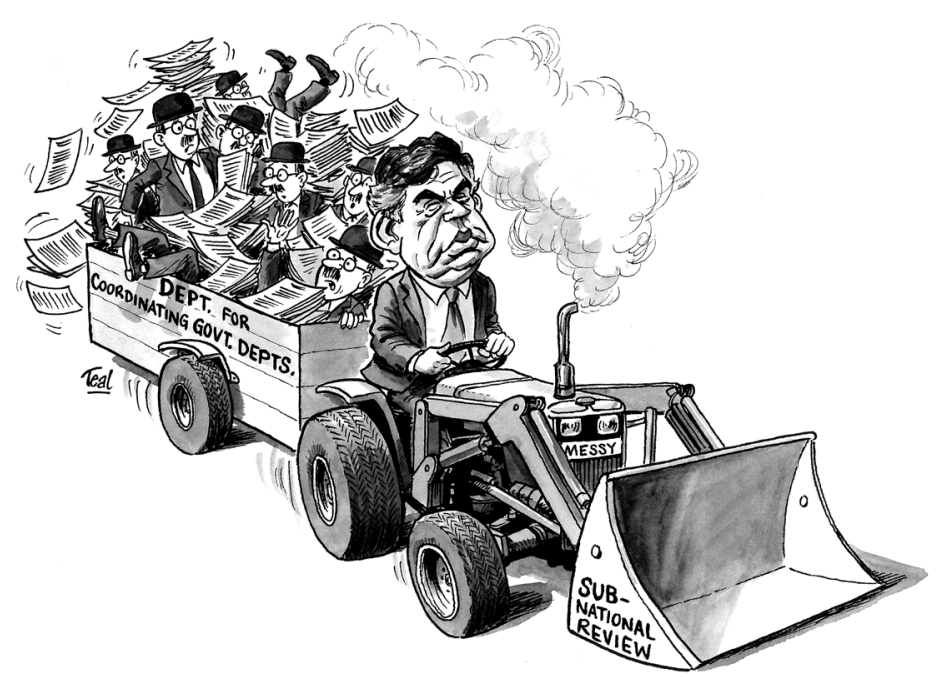

Source: Original commissioned artwork, drawn by Adrian Teal.

\section{Figure 1.5 Crisis-analytic depictions of the sub-national review}

Peyton of Yeovil, criticising the government's neighbourhood renewal unit at that time:

The organization has no fewer than seven divisions and 14 subdivisions. Its habit of breeding, which is endemic in the Office of the Deputy Prime Minister, has spread to boroughs. The government has produced an indissoluble union between gobbledy and gook. (quoted in Weaver 2003: 17)

Throughout this period, as Deas and Ward (1999: 130) highlight, the new localist 'song' had mostly ended, but the complexity 'melody lingered'. In other words, this new regionalism is 'just one element in a wider complex of overlapping agencies, structures and policies, the logic and coherence of which remains to be proven'. Local Strategic Partnerships (LSCs) and later a series of Area Agreements (Local then Multiple AAs) were deployed so that local stakeholders could work together to agree and deliver local policy priorities within this quagmire, but, with limited statutory powers and minuscule budgets, the government's increasingly performance management regime for government programmes largely bypassed the new structures and added to the existing complexity (Chapter 7). This is evident by the rapidity of institutional developments in Figures 1.1-1.4, culminating ultimately in what Sullivan 
and Skelcher (2002) refer to as a 'congested state', in which a 'considerable amount of time and resources are chewed up in getting new organisations off the ground and in constructing partnership relations so that something might get done' (Corry and Stoker, 2003: 10, emphasis added). Figure 1.5, sketched during the period of the 2009 sub-national review, seeks to capture this.

\section{New New Localism: Devolution Deals and Beyond}

The resulting spatio-temporal fix to deal with this dysfunctional multi-scalar complexity increasingly became a 'new new localism' of city-regions, given the desire to create institutional projects able to hold-down the global through functional economic areas (Chapter 8). The HM Treasury (2007) sub-national review (SNR) had proposed Urban Regeneration Companies (URCs) and subregions became key spatial units in increasingly devolved contexts (see Ayers and Stafford 2009). Post 2010, a Devolution and Local Government Act and Local Growth agenda pushed 'functional economic areas' further through LEPs, City Deals and Devolution Deals (Chapters 9 and 10). The Royal Society of Arts' (RSA's) City Growth Commission represented a key moment, leashing metro-growth, through a series of city-regions, or 'metros'—defined as the 'larger constellation of cities and towns that constitute a functional economy within built up areas' (RSA 2014: 11)—with critics noting this fuzzy-space city-region building as adding further to the tangled problem of governance complexity; nothing short of an imbroglio of institutional crises that reproduces the labour market deep inequalities by focusing only on the most profitable and high-tech sectors of the local and regional economy (Etherington and Jones 2016a). Moreover, there is little new money, more a 'menu of specials', where:

A number of items have been made available to most areas, but each deal also contains a few unique elements or 'specials' (typically consisting of commitments to explore future policy options). (Sandford 2018: 9)

While the principal historical function of local authorities was the concern with delivering public services in the context of addressing the fallout of uneven development (Duncan and Goodwin 1988), merging LEPs with local government functions through the various Combined Authorities (CAs) and Mayoral CAs (see HCLG 2018) twisted and turned the function of the local state towards the ideological purpose of economic growth 'by negotiation' with central government (see Hatcher 2017; O'Brien and Pike 2018). The deployment of depoliticising processes are crucial here to limit opposition and resistance (see Chapters 10 and 11), alongside the ongoing process of joining up economic development with the market-making and welfare reform 
agenda (see Hackett and Hunter, 2017), given policy desire to have locally sensitive and coordinated approaches (Mawson 2009), drawing on the lessons of the Prototype Employment Zones (Chapter 4) and City Strategy Pathfinders (Chapter 7). Back to where I started on LEPs, for Toynee and Walker, making the link between state 'dismembering' and waves of privatised localism:

[LEPs] are wonderful specimens of the administrative exotica created by ministers who would rather do nothing but can't get away with it. In 2010 they summarily abolished the regional economic development agencies: clearing the ground for a market solution. But business in the regions demanded a replacement, hence LEPs, which are committees of local businesspeople who give grants to ... local businesspeople. (Toynbee and Walker 2017: 78, emphasis added)

Consequently, noting what Peck (2010: 16) calls 'state/market configurations' these activities have been bringing with them 'authoritarian politics' with deep consequences across cities and regions, as inherited and hard-won forms of popular control over welfare state institutions are being gradually eroded. Insofar as they have entailed a 'productivist' reordering of social policy and the increasing privileging of economic competitiveness (Brenner 2004), shifts to entrepreneurial governance have also contributed to a reduced commitment to the concerns of collective consumption for poorer sections of society. For Harvey (2005: 76) 'a way has been found to integrate state decision-making into the dynamics of capital accumulation and the networks of class power'. Accordingly, the move from RDAs to LEPs effectively removed two-thirds of core regeneration and ended the 40-year history of area-based regeneration initiatives 'targeted at the most deprived parts of England' (Crowley et al. 2012; Hetherington 2013). As Hall summarises:

the Conservatives and Liberal Democrats have pre-sided over the effective cessation of urban regeneration as a form of public policy. Legacy programmes have been allowed to expire without replacement or, in the case of Housing Market Renewal, simply terminated. Total government expenditure on regeneration was reduced by some two-thirds within the financial year 2011/2012. For the first time since the $1960 \mathrm{~s}$, there is no national framework of area based regeneration initiatives and supporting financial and institutional resources in the cities of England ... Indeed, it can be argued that the Coalition government has rejected a role for itself in respect of the monitoring and elimination of poverty and social exclusion. (Hall 2016: 324, emphasis added)

New landscapes of power have indeed been created in this gap, in which new forms of exclusion, subordination, and also resistance are inscribed into urban and regional space (Ellis and Henderson 2013). One notable ingredient in this political endeavour has been escalating welfare-to-work or 'workfare' interventions (see Chapters 4, 7, 10), which aim to secure a new relationship 
between the state and its subjects by requiring work or active labour market activities in return for unemployment benefit and welfare assistance. The discussion on the rollout of Universal Credit, which involves replacing six means-tested benefits for working-age households (see Chapter 10), is the culmination of this regime, with the National Audit Office (2018) raising serious questions on the operability of a system that is causing hardship and misery for thousands.

\section{Neoliberalism and its Spatial Conditions}

This neoliberal growth strategy should neither be seen as an all-encompassing, universal and settled project, nor a binary process of switching one spatial scale with another (local-regional and regional-local). In the words of Brenner et al.:

To speak of neoliberalism 'in crisis' needless to say, presupposes an understanding of the character of this elusively dispersed yet deeply embedded form of social rule. A singular, monolithic and unified neoliberalism might indeed be prone to a correspondingly 'total' crisis. But neoliberalism has never displayed such a singular, monolithic character. It may be deeply integrated, but it has always been unevenly developed-most notable across nations, cities and regions ... [N] eoliberalism's proven capacities in the (downward and outward) displacement and (forward) resheduling of risks and crisis tendencies mean that its associated regulatory landscapes are especially dynamic. (2012: 17-18)

It is important, then, to highlight the contingent 'mechanisms' or 'processes' in and through which this project is being politically made and contested with 'some forms of agency' to avoid 'over generalizations' (Le Galès 2016: 168). Following Offe (1984: 37), Cities and Regions in Crisis favours a 'processual' approach, which seeks out the mechanisms ('cross-scalar relations' as Brenner et al. (2012: 60, emphasis original) put it) that generate events and can highlight developmental tendencies and tease out important counteracting tendencies and opportunities for progressive localisms. All this raises some searching questions, which Cities and Regions in Crisis seeks to address. How is the 'relativisation of statehood' (Collinge 1999) unravelling in different geographical contexts and is there an emerging spatio-temporal fix to replace the primacy of national territory, national economic space, national social formation, and national networks? Are new forms of state configuration emerging that seem to be consolidating and ossifying to create a relatively stabilised landscape of regulation, or are multispatial arrangements set to continue with an ongoing search for different possibilities? Figure 1.4 indicates an increasingly multispatial economic statehood, where no single scale is dominant, but where nodes of activity appear to be settling then shifting periodically. Are 
multiple rounds of 'filling-in' occurring, which challenges assumptions that with globalisation the state is 'hollowing out', declining, and being eroded away (Goodwin et al. 2012, 2017)? Who has access to the state apparatus; who participates when and how? What is the relationship between different types of state and non-state actors and between different levels? How are issues of democracy and legitimacy dealt with? And how are the conflicting demands of competitiveness, cohesion, and sustainability dealt with?

Cities and Regions in Crisis tackles these and thus gives an insight into the ways in which state actors walk a difficult line between ensuring the right environment for economic growth and development but at the same time guarding against a crisis of electoral support (issues of legitimation crisis). Instances of regulatory failure across cities and regions are becoming apparent, as state policy-making constantly switches economic problems in concerns of state rationality that can be more easily addressed through public policy. State actors appear to be continually reinventing policy initiatives, often in response to the problems and contradictions caused by previous rounds of state intervention, in a search to get things right. As Brenner et al. put it:

the practice of neoliberal statecraft is inescapably, and profoundly, marked by compromise, calculation and contradiction. There is no blueprint. There is not even a map. Crises themselves need not be fatal for this mutable, mongrel model of governance, for to some degree or another neoliberalism has always been a creature of crisis. But selectively exploiting the crisis of Keynesian-welfarist, developmental or state-socialist systems is one thing, responding to crises of neoliberalism's own making is quite another. (2012: 45)

How are state actors dealing with these challenges, that is, how is failure being presented and interpreted, addressed, new solutions proposed, and are these becoming successful? Provisional answers to these big questions are below.

\section{SPATIAL DIVISONS OF THE STATE: MULTISPATIAL METAGOVERNANCE AND THE NEW GEOGRAPHIES OF ECONOMIC DEVELOPMENT}

Cities and Regions in Crisis demonstrates the unravelling of the Keynesian welfare national state institutional compromise and the making of a crisis space impedimenta neoliberal state. Figure 1.6 depicts how this has been playing out in the field of local and regional economic and social development over the past 40 years. A pendulum swing effect has been experienced, whereby UK state strategy, in turn linked to how the policy problem is constructed and its solution articulated, has moved and oscillated between national, regional, and local patterns of state projects and modes of state interventions. The previous round of state spatial restructuring has been used as the explanation for state 
1800s to 1920s:

Municipal

Localism

1979 to 1997:

Thatcher-Major

New Localism

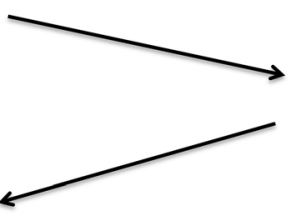

1930s to 1970s:

One Nation Consensus

Regionalisms

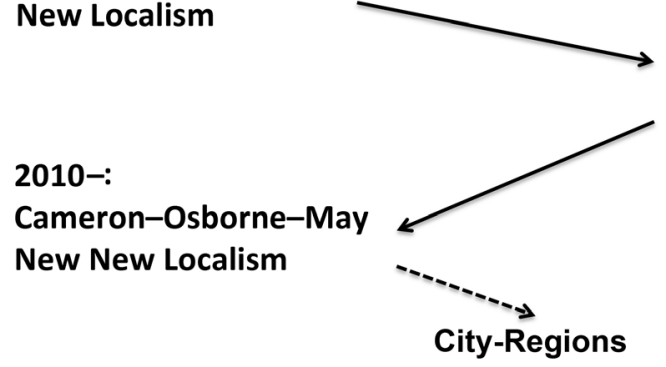

\section{Localism}

\section{Regionalism}

Source: Adapted and updated from Pike et al. (2016b: 10).

\section{Figure 1.6 Pendulum swings in governing economic development}

intervention failure, with the next round seeking to address this through developing new spatial horizons, also failing in turn (Jones and Ward 2004). Part I (Chapters 2, 3, and 4) examines the 'new localism' of the Conservative Party administration (1979 to 1997). Part II (Chapters 5, 6, and 7) turns to look at the 'new regionalism' of the Labour Party administration (1997 to 2010). Part III (Chapters 8, 9, 10) unpacks the 'new new localism' of both the Coalition administration (2010 to 2015) and the return of the Conservative Party (2015-).

What becomes apparent from these local and regional economic development journeys is the appropriateness of not talking of a single crisis and in mono-causal terms (MacLeod and Jones 2018). Cities and Regions in Crisis is embedded in a political economy tradition where the interrelationships between economic, social, and political processes, which are forged through power relations as 'moving parts', matter. The book offers a multi-causal approach to crises and thereby expands the definition of crisis by initiating a movement from the primacy of the economy, to the primacy of the state, and then to the primacy of the political. Combining these approaches and 'doing political economy' facilitates the study of how the inherent contradictions and crisis tendencies of capitalism are governed within economic development and through a historically variable set of institutional, spatio-temporal, and 
semantic fixes - all partial, provisional, and temporary. Subsequent chapters accordingly offer a neo-Marxist syncretism by building on Marxism and Frankfurt School Critical Theory (Chapter 3), regulation approaches and strategic-relational state theory (Chapters 2, 3, 4, and 10), associative institutional theories (Chapters 5 and 6), relational approaches to space and place (Chapters 7 and 8), and cultural political economy framings of politics and depoliticisation (Chapters 9 and 10) to collectively argue that policy actors, politicians, and business leaders are locked into the market model of delivery, neoliberalising modes of representation, and subsequent failures in economic regulation and governance. The book illustrates how local and regional economic development has a 'deficit in local regulatory capacity' and some state forms and functions have clearly become 'counter-regulatory' (Painter and Goodwin 2000). Governance failure (a response to both state failure and market failure), i.e. the 'failure to redefine objectives in the face of continuing disagreement about whether they are still valid for the various partners' (Jessop 2000: 18), is occurring.

There are a number of dimensions to governance failure, which are embedded in economic development (see Etherington and Jones 2016a, 2018). First, is the apparent tension between devolving responsibilities in relation to policy formation and implementation and the tendency towards centralisation in decision making, whereby local actors are charged with implementing nationally determined targets and programmes. The challenge here is the adaptation of national programmes to local conditions.

Second is the increasing tendency towards institutional and policy fragmentation at the sub-regional level, with issues of accountability being raised. Governance becomes a new site for conflicts and political mobilisation, as the nature and complexity of partnerships means more and more 'actors' and 'stakeholders' involved in the design and delivery of labour market programmes. Outcomes at one scale may be dependent upon performance at another scale of governance, therefore coordination dilemmas can occur. Furthermore, these coordination mechanisms may have different 'temporal horizons' and there may be continuous tensions between short-term and long-term planning goals in policy planning.

Third, and related, is the failure of current policies to address deep-rooted problems of labour market inequalities that are integral to market failure. This is exemplified in many localities by the employment gap and lack of sufficient sustainable employment growth to 'revitalise' city-region economies. Finally, governance in the form of economic partnerships, dominated by private sector interests, is continuing to replace elected and representative government in terms of local economic development, which in itself poses a number of problems between government and its elected representation model of democracy and partnerships, and which tend to be elite-forming with blurred lines 
of accountability, often far removed from those who are disadvantaged and disenfranchised. Depoliticisation is also occurring and increasing (Fawcett et al. 2017), as opaque representational structure and lines of accountability close down and restrict possibilities of negotiation and contestation (see Chapter 10).

As noted by Bakker (2010), these processes have been neither 'tidy in practice' nor 'linear in fashion': market failures, state failures and governance failures coexist, 'exhibit a range of failures', and are used to justify the 'problem' requiring ongoing state intervention. It is, therefore, important to consider notions of 'crisis metamorphosis'. Thompson distinguishes this from the approaches of Harvey (above) and Habermas (see Chapter 3 ) by insisting that:

Metamorphosis implies a change in form; it does not imply, as displacement does, that the crisis has moved from one sphere of social life to another. A financial crisis that metamorphoses into a political crisis or a social crisis does not necessarily cease to be a financial crisis: it simply becomes something else. It changes form and, in doing so, it becomes something more than a financial crisis per se, taking on new characteristics in the process. (Thompson 2012: 64-65, emphasis original)

Moreover, as forms of governance become more widespread and constantly change their form (metamorphosis) 'the question of governance failure becomes more acute' (Bakker 2010: 45). The state's answer to governance failure is to develop forms of metagovernance, which involves attempts to manage the ongoing complexity, plurality, and tangled hierarchies characteristic of prevailing modes of coordination (see Jessop 2000, 2008, 2016a). It involves, then, continually defining and redefining boundary-spanning roles and functions, creating and recreating networking and linkage devices, sponsoring and redesigning new institutions, identifying appropriate lead strategic institutions to coordinate other partners, and continually generating discourses and narratives on the economy (the 'shaping of context', according to Jessop 2011) to facilitate relative geographical coherence through repetition of the 'problems' to be addressed and the solutions to these-metamorphosis played out.

Government plays an increasing role in metagovernance: providing the ground rules for governance and regulatory order in and through which governance partners can pursue their aims and seek to ensure the compatibility or coherence of different governance mechanisms and regimes; seeking to balance and rebalance power differentials by strengthening weaker forces or systems in the interest of social cohesion or integration; and providing political responsibility in the event of governance failure (Etherington and Jones 2016a; Whitehead 2003a). These emerging roles mean that networking, negotiation, noise reduction, and negative as well as positive coordination occur in the shadow of hierarchy'. It also means that, as Jessop reminds us, there is 'the need for almost permanent institutional and organizational innovation to 
maintain the very possibility (however remote) of sustained economic growth' (Jessop 2000: 24). Economic development initiatives are thus frequently produced through a combination of political fiat, central government diktat, and local state opportunism. The research agenda put down by Jessop for doing metagovernance, which Cities and Regions in Crisis addresses is the:

extent to which the multiplying levels, arenas, and regimes of politics, policy-making, and policy implementation can be endowed with a certain apparatus and operational unity horizontally and vertically; and how this affects the overall operation of politics and legitimacy of the new political arrangements. (Jessop 2008: 222)

Effective governance and metagovernance, in turn, depend on displacing (via the metamorphosis of the problem and its solution) certain governance problems elsewhere and/or on deferring them into a more or less remote future. This is possible because the state can transform its own internal structures and patterns of intervention spatially in an attempt to temporarily reconcile the contradictions inherent in its involvement in economy and society (Hudson 2001). Whereas the positively charged policy-context of many of the chapters below point to a can-do 'steering optimism', where there is deemed to be a capacity to engage fruitfully and with purpose to produce temporary spatio-temporal fixes, Cities and Regions in Crisis points to 'steering pessimism' and a 'crisis of crisis-management' (Offe 1984). In short, state intervention has come to operate not only as a political strategy for promoting local economic development, but also as a form of crisis-management designed to manage the regulatory deficits, actor dislocations, and geographical conflicts induced through earlier rounds of state spatial restructuring (Jones and Ward 2004). As the various chapters seek to demonstrate:

a crisis-induced recalibration has been unfolding since the mid-1990s [whereby] a rescaled layer of state spatial projects and state spatial strategies has been forged whose purpose is to confront some of the major regulatory failures generated through state intervention. (Brenner 2004: 266)

In turn, there are structural economic obstacles to effective governance and metagovernance, that, "by virtue of the simplification of the conditions of action, so often lead to the "revenge" of problems that get ignored, marginalized, displaced, or deferred' (Jessop 2011: 117). Figure 1.7 summarises the key dimensions of this geographical political economy conceptualisation of crisis and contradiction theory and points to the importance of the accumulation, and inescapable intensification, of the unresolved contradictions of doing local and regional economic development. Brenner (2004: 263-265) neatly summarises these as the outstanding problems of: inefficiency and waste; chronic short-termism; regulatory undercutting; increasing uneven spatial develop- 




Source: Author's analysis.

Figure 1.7 The geographical political economy of crisis spaces

ment and territorial conflicts; problems of interscalar and inter-territorial coordination; democratic accountability and legitimation problems. For Fuller and Geddes, this gambit of regulatory problems and crisis-tendencies likewise revolves around:

tensions between nation-state control of urban regulatory spaces and local autonomy and discretion; the challenges created by the focus on 'joining up' agents in urban spaces for purposes of addressing deprivation; and issues around the extent to which communities and citizens have the capacity to lead and influence governance arrangements within the context of devolved responsibility. (Fuller and Geddes 2008: 266)

The various chapters of Cities and Regions in Crisis provide empirical reflections on this 'crisis space' (Hadjimichalis 2018) in action. The solution to metagovernance failure is the state's ability to undertake, through further acts of spatial movement and geographical displacement, multispatial metagovernance (MSMG). According to Jessop (2016b), this recognises the complex, reciprocal, and interdependence of several spatio-temporal social fields that 
the state can draw on to frame its modes of intervention and policy-making capacities. The basis of this rests on earlier work with colleagues on the 'TPSN schema' (denoting the concepts of territory, place, scale, and network), which explored the interaction between these four spatial moments of social relations considered both as structuring principles and as fields of socio-spatial organisation (see Jessop et al. 2008). These moments of socio-spatiality, which seek to go beyond analysis of the state in one-dimension, can be combined to produce more concrete-complex analyses of particular socio-spatial configurations, tied to specific substantive relations and processes, and articulated in different kinds of state spatial strategy to intervene in the economy. Each socio-spatial organising principle, then, has its own forms of inclusion-exclusion and entails differential capacities to exercise state powers. This opens a strategic field in which social forces seek to privilege different modes of socio-spatial organisation to privilege their ideal and material interests. Moreover, strategies of crisis resolution involve attempts to reorder the relative importance of the four dimensions and their associated institutional expressions and, hence, to modify the weight of their role in displacing crisis tendencies and contradictions - moving them around as Harvey (2011) put it.

Table 1.1 accordingly summarises how all the spatial combinations have been used as sites for doing local and regional economic and social development over the past 40 years. A discernible shift can be noted, whereby: place-place state spatial strategies of the Victorian's localist era existed; territory-place strategies of the spatial Keyensian welfarist era replaced this regulatory fix; place-network and scale-network forms of neoliberal state intervention were dominant the new localism and new regionalism; and network-place state spatial strategies are the game face of the new new localism. This generalisation, though similar to other European experiences (see Piattoni and Polverari 2016; Bachtler et al. 2016), conceals some of the relativisation tendencies at work (see above). In terms of metagovernance, as the chapters of Cities and Regions in Crisis reveal, competing and rivalled socio-spatial strategies have existed and coexist. Attempts to collibrate the relative weight of the socio-spatial configurations, illustrated by the state project descriptions in these cells, have indeed failed to create a stable economic and social compromise-instead 'intensify[ing] uneven development, especially when declining regions are blamed for their own decline, required to make themselves attractive to capital based on mobilizing their own resources, or left to rot' (Jessop 2018: 7).

A lack of symmetry accordingly now exists between the 'spatial division of labour' (Massey 1984)_put simply, the geographical organisation of relationships on production and accumulation-and the 'spatial division of the state' - put simply, the relationships horizontally and vertically within and between forms of regulation and governance. Moreover, these two spatial 
Table $1.1 \quad$ The multispatial metagovernance of economic development

\begin{tabular}{|c|c|c|c|c|}
\hline \multirow[b]{2}{*}{$\begin{array}{l}\text { Structuring } \\
\text { fields }\end{array}$} & \multicolumn{4}{|c|}{ Structuring principles } \\
\hline & Territory & Place & Scale & Network \\
\hline Territory & $\begin{array}{l}\text { Territorialisation } \\
\text { of local authorities, } \\
\text { creation of local } \\
\text { state institutions } \\
\text { (e.g. TECs, LEPs) }\end{array}$ & $\begin{array}{l}\text { Management } \\
\text { of uneven } \\
\text { development, } \\
\text { integrating places } \\
\text { into a territory } \\
\text { (e.g. Urban } \\
\text { Programme) }\end{array}$ & $\begin{array}{l}\text { Spatial } \\
\text { Keynesianism, } \\
\text { coordinating different } \\
\text { scales (e.g. Regional/ } \\
\text { Urban Development } \\
\text { Policy) }\end{array}$ & $\begin{array}{l}\text { Multi-area } \\
\text { government and } \\
\text { governance (e.g. } \\
\text { Government Offices } \\
\text { for the Regions, } \\
\text { CAs) }\end{array}$ \\
\hline Place & $\begin{array}{l}\text { Land-based agencies } \\
\text { with zonal-extent } \\
\text { (e.g. UDCs, EZs, } \\
\text { English Partnerships, } \\
\text { URCs) }\end{array}$ & $\begin{array}{l}\text { Designating } \\
\text { towns and cities, } \\
\text { contiguous regions } \\
\text { and city-regions }\end{array}$ & $\begin{array}{l}\text { Glocalisation, } \\
\text { glurbanisation, } \\
\text { urban-global } \\
\text { interrelationships }\end{array}$ & $\begin{array}{l}\text { Local, urban, } \\
\text { regional governance } \\
\text { partnerships (e.g. } \\
\text { Single Regeneration } \\
\text { Budget, City } \\
\text { Challenge, LSPs, } \\
\text { LAAs, MAAs) }\end{array}$ \\
\hline Scale & $\begin{array}{l}\text { Filling-in of } \\
\text { administrative } \\
\text { functions: Unitary, } \\
\text { District, Borough } \\
\text { institutions }\end{array}$ & $\begin{array}{l}\text { Twinning } \\
\text { arrangements, } \\
\text { local-global } \\
\text { linkages }\end{array}$ & $\begin{array}{l}\text { Soft or fuzzy spaces, } \\
\text { non-contiguous } \\
\text { city-regions (Core } \\
\text { City and Key City } \\
\text { networks) }\end{array}$ & $\begin{array}{l}\text { Nested or tangled } \\
\text { scalar projects (e.g. } \\
\text { RDAs, Regional } \\
\text { Assemblies) }\end{array}$ \\
\hline Network & $\begin{array}{l}\text { Spatial Imaginaries, } \\
\text { virtual, relational, } \\
\text { and cross-border } \\
\text { regions (e.g. } \\
\text { Northern } \\
\text { Powerhouse, } \\
\text { Midlands Engine) }\end{array}$ & $\begin{array}{l}\text { Polycentric cities } \\
\text { and multi-city } \\
\text { regionalism, } \\
\text { deal-making } \\
\text { policy (e.g. City } \\
\text { Deals, Devolution } \\
\text { Deals, Sector } \\
\text { Deals) }\end{array}$ & $\begin{array}{l}\text { Private international } \\
\text { regimes, providers } \\
\text { of state services } \\
\text { (e.g. Work and } \\
\text { Health Programme, } \\
\text { Transport } \\
\text { Infrastructures) }\end{array}$ & $\begin{array}{l}\text { Fast-policy transfers, } \\
\text { networks of networks } \\
\text { (e.g. Business } \\
\text { Improvement } \\
\text { Districts) }\end{array}$ \\
\hline
\end{tabular}

Note: TECs: Training and Enterprise Councils, LEPs: Local Enterprise Partnerships; CAs:

Combined Authorities; EZs: Enterprise Zones; UDCs: Urban Development Corporations; LSPs: Local Strategic Partnerships; LAA: Local Area Agreements; MAA: Multi-Area Agreements; RDAs: Regional Development Agencies.

Source: Adaptation and application of Jessop et al. (2008: Table 2).

divisions are interrelated, as '[v]ariations in the role of the state are a result of a number of factors, including the structure of industry, administrative organization, and the character of the ruling political coalition' (Dunford and Perrons 1992: 391). Building on the notion of 'regulatory capacity', the state, then, is part and parcel of the coordination deficit dilemma of economic development as a result of a problem of 'territorial non-correspondence', as Cox (2008: 342) 
puts it-i.e. the desire and need to have competence, influence, and where control is out of reach and exceeded by capacities occurring at other territorial scales. The answer is not to seek a resolution through coterminous boundary drawing (cf. Ney 2017; HCLG 2018), but to challenge the fundamental spatial and geographical logic of the British growth model and the ways in which the forces of capital actively help to produce and reproduce combined and uneven development. The challenge to this has frequently come from those advocating new spaces of citizenship and belonging through the windows of state spatial restructuring. Chapters 6, 9, and 10 flesh out some of the opportunities for, and limits to, civil society place-attachments in the 'new regionalism' and 'new new localism' strategies, noting practices in the field of 'contentious politics' (Nicholls et al. 2013) within local and regional economic development.

\section{Brexit Impedimenta: Revenges of Uneven Development and Inequality}

In summary, Cities and Regions in Crisis argues that the growth of neoliberal modes of intervention, driven by absorbing market failures into the state apparatus, which in turn leads to state and governance failures in new, and old, institutional and spatial forms (Figure 1.7) has led to an 'impedimenta state' (Jones 2010) - the capitalist state with accumulated ambivalence and disorientation, increasingly weighed down by policy journeys travelled in local and regional economic development. In situations of crisis-management, the best that policy-makers can hope for is a series of temporary and temporal 'crisis spaces' (Hadjimichalis 2018) of conflict solution, which can only stall crises for limited moments, as the accumulation of unsolved contradictions mounts up to impedimenta proportions. The state has baggage and is increasingly bag-like in its appearance, accumulated actions, and reactions. The trouble with bags, though, is that they demand to be filled, and impedimenta, like some parasitic virus, seem to rapidly replicate geographically. The evidence provided here points to the state carrying a rucksack or trailer of crisis legacies over time, which is getting heavier into coming years of policy-making. This is being derived from the state responding to problems caused by its own interventions, attempting to leave behind accumulated policy legacies, such that the state has become irrational and a site of, and for, bureaucratic ponderousness in and through administrative inertia and modes of negative coordination. As predicted 50 years ago, not dealing with this would result in problems of both 'state rationality' and a 'legitimation crisis' (see Chapter 3).

The cohesion of societies ... can be maintained only by an incoherent mixture of ideology, violence, pressure and repression. The authoritarian actions of the state cannot resolve either old or new contradictions; they try to evade their impact by reducing problems and possibilities. By utilizing for this irrational and 
specialized - i.e. reduced and reductive - activities, political action pretending to totality becomes itself reduced and reductive. This gives rise to new contradictions. (Lefebvre 1969: 136, emphasis removed)

The 23 June 2016 vote in Britain to 'Brexit' the European Union was in large part driven by those in distressed rust-belt post-industrial areas, disenfranchised within an impedimenta state 'geography of discontent' (Los et al. 2017) and lacking confidence in politicians and policy-makers to manage economy and society through the various rounds of industrial restructuring-induced economic development over the past 40 years. In Elliott's eyes:

old industrial Britain is still suffering from the consequences of the closure of factories and pits three or four decades ago. These communities have higher levels of unemployment and higher concentrations of people on disability benefit, and have suffered much more grievously from government welfare cuts. Unsurprisingly, they were also strongly in favour of leave. North of the line that runs from the Severn estuary to the Wash, Brexit was the culmination of a 40 -year process of de-industrialisation and casualisation of work. It was a protest about dead-end jobs, and about run-down communities being lorded over by London, talked down and bossed around. (Elliott 2017: 12)

This is the 'revenge of the places that don't matter' as Rodríguez-Pose (2018: 189) puts it, and this book's 'Postscript' discusses how this has been playing out in the Stoke-on-Trent city-region, which lends itself to a multi-causal analysis of crises (see also MacLeod and Jones 2018). British economic development does not have to be this way. Part IV discusses some alternative pathways to this crisis end-point by, first, engaging with contemporary analyses of inclusive growth and the place of civil society in Britain (Chapter 11). Chapter 12 discusses a 'negotiated' model of economic governance in Denmark, recalled from a period of silence with this kind of thinking in Britain (Etherington and Jones 2004a, 2004b), which I argue remains increasingly valid for addressing the contradictions of neoliberalism and the crises facing our cities and regions. Chapter 12 highlights how institutional, spatio-temporal, and semantic fixes work best when they connect different spheres, scales, and institutional sites of social action and have in-built sources of redundancy and flexibility that can be mobilised in the face of instability or crisis. 